UDC 551.4:551.435:504.064.3(477.83)

\title{
STRYVIHOR RIVER SYSTEM STRUCTURE TRANSFORMATION
}

\author{
Andriy Mykhnovych \\ Ivan Franko National University of Lviv, \\ Doroshenko Str., 41, UA - 79000 Lviv, Ukraine
}

\begin{abstract}
River basin sustainable development demands the investigations of the river network space and time dynamics - central integrating component. Especially this problem regards to the river system structure and its transformation. Depending on the differences in the economical development history of the Stryvihor basin on the territory of Ukraine and Poland this river is very interesting in the aspect of forestry, agriculture, settlements influences upon the river systems structure changes. So the subject of inquiry is the Stryvihor River basin. The main objective of investigation is the river system structure analysis and evaluation of the trends and scales of structure changes. River system structure was analyzed by the classification scheme of Strahler-Filosofov applying methods of statistical and cartometrical analyses and mapping. Information source for investigations is topographical maps of the scale 1:100 000. The structure is described by the series of morphometric parameters. The river system structure change is evaluated by comparing the transformation coefficients and river density parameters for the years 1875 and 2005.

The Stryvihor headwaters, Lodyna and Stebnyk rivers are characterized by $5-10 \%$ less amount of disappeared rivers and $10-20 \%$ less shortening of their total length. Typical for the Stryvihor river basin very high bifurcation coefficients testify about strong sensibility and poor stability of the rivers against man-made pressure and different economical activities. In compare to year 1855 the ratio between different orders has changed on $10-25 \%$.

Key words: river system structure, river order, river network density, transformation.
\end{abstract}

Introduction. Investigations directed on the river system structure assessment based on its description by the special morphometric parameters and ascertaining of the geographic regularities of the river system structure forming and transformation start from the researches of the well known American geomorphologist R. Horton. Later this scientific direction was continuing and developing in the papers of Strahler (1952), V. Filosofov, N. Makkaveev (1955), R. Shreve (1966), I. Hartsman, Y. Simonov, O. Borsuk, V. Shmykov (1986), I. Kovalchuk (1992, 1997), P. Shtoyko (1992), S. Volos (1992, 1999), B. Neshataev (1992), Y. Silets'kyi (1992), L. Dubis (1995), A. Mykhnovych (1998), Y. Kyseliov (2000), L. Kurhanevych (2001), T. Pavlovs'ka (2006) and many others $[1-4,6-9,11,12]$.

In the second half of XX-th century considerable results were achieved in the following directions: study of distribution and geomorphologic effects of the erosionaccumulation processes in the river valleys of different regions (G. Shvebs, A. Pozdniakov, I. Chervaniov, I. Kovalchuk, Y. Khomyn, L. Dubis, O. Obodovs'kyi and others); intensive use of the system approach for fluvial processes and relief forms investigations (O. Kashmens'ka, R. Chalov, V. Kruzhalin, I. Kovalchuk, I. Chervaniov, Y. Yushchenko, Y. Symonov and others); Stationary and experimental investigations of erosion processes (O. Boliukh, G. Shvebs, I. Kovalchuk); river

(C) Mykhnovych A., 2018 
system structure transformation in different geographic regions etc.

The last one plays one of the central roles in the complex river basin geosystems analysis. In the river network pattern the essential information on geological, geomorphologic, hydrologic aspects of river basin systems origin and development is coded. So river system structure investigations first of all are directed upon evaluation of its role in catchment geomorphologic systems functioning and evolution. By that the elements (or subsystems) of the catchment system interact each other according to the certain regularities. The mechanism of this interaction is directed upon achievement and keeping of the equilibrium of the system [2].

The subject of inquiry is the Stryvihor River basin and its river system. The main objective of investigation is the river system structure analysis and evaluation of the trends and scales of structure changes.

Materials and methods. River systems functioning can be studied by space and time characteristics of their structure analysis. River system structure analysis allows determining certain norms or optimal state of self-regulated river system. It is very important task for planning and management of the sustainable natural-economical basin systems [2]. Rivers of different orders interact in the junctions. By rise or disappearance of elementary stream the mechanism of balance achieving is changed. It means the water and sediments runoff, correlation between erosion, transportation and accumulation are changed. River system structure transformation is rising or disappearance of the streams or system order change.

River system structure was analyzed by the classification scheme of StrahlerFilosofov applying methods of statistical and cartometrical analyses and mapping. According to the Strahler-Filosofov scheme the elementary river valley is permanent stream without tributaries on a topographic map. Information source for investigations is topographical maps of the scale 1:100 000. This scale maps visualize almost all permanent rivers of more than $100 \mathrm{~m}$ length. The structure is described by following parameters: amount of the certain order rivers, their total and average length, percentage ratio of every river order by total river amount and total length, bifurcation coefficient $\left(b=n_{1} / n_{2}\right.$, where $n_{1}$ i $n_{2}$ - rivers amount of the first and second orders accordingly) reflected ratio between the total rivers amount of neighbor orders, river network density $[1,2,9]$.

Structure transformation is assessed applying the historic-geographic, statistical, comparing, morphometric methods. The quantitative assessment of the change scales is worked out by the transformation coefficient in percents. To ascertain the tendencies and scales of the transformation the structure parameters for two time records have been compared (years 1875 and 2005). To determine the space particularities of the river network structure and density the tables with morphometric parameters and the density cartograms for different time records as well as tables and cartogram of transformation parameters have been created. The parameters of total river amount and total river length changes have been calculated. Transformation parameters were calculated as percentage ratio of the certain order rivers amount (or total length) between the end and start of the analyzed period.

Study sites. The Stryvihor River belongs to the Dnister River basin and is left tributary of its upper part. The river runs through the territory of Poland and Ukraine. The total length is $94 \mathrm{~km}$ including $77 \mathrm{~km}$ within Ukraine. The catchment area 
amounts $955 \mathrm{~km}^{2}$, forested area is about $28 \%$, swamped area occupies about $1 \%$, and arable lands amount about $38 \%$ [10]. The river spring is located to north-west from Ustrzyki Dolne town (about $640 \mathrm{~m}$ above sea level) in Poland. The river has 7 tributaries with of more than $10 \mathrm{~km}$ length (total length amounts $134 \mathrm{~km}$ ). The river density (without small rivers with the length up to $10 \mathrm{~km}$ ) is $0,24 \mathrm{~km} / \mathrm{km}^{2}$. Altitude difference between the river spring and mouth is $377 \mathrm{~m}$, the average inclination amounts $1,7 \mathrm{~m} / \mathrm{km}$. Water runoff norm is 265 millions $\mathrm{m}^{3}$, in the years of $75 \%$ probability the runoff amounts 202 and in $95 \%$ probability it is equal 139 millions $\mathrm{m}^{3}$. The water runoff is regulated in $1-2 \%$. The total amount of ponds and reservoirs in the basin is about 100 .

The Stryvihor basin is situated within the Precarpathian depression. Geologically it is composed with the sediments of Quaternary, Neogene, Paleogene and UpperCretaceous periods. The watershed is situated within the two geomorphologic regions: the Carpathian low mountains relief of the North-Western Beskyds with structuralerosional and denudational-erosional forms (upper part of the catchment) and Precarpathian fluvial-accumulation relief of the Sian-Dnister interfluve (lower part). The bigger part of the river basin occupies two morphostructures of third order: Stryvihor-Bolozivka upland with denudational-accumulative and erosional-structural relief and the Sian-Dnister upland with denudational-accumulative relief domination. Both units concern to the Stara Sil-Hodnovytsia transverse height [5].

Low mountain relief is characterized by soft contours and looks like gently-sloping wavy hills with altitudes $500-600 \mathrm{~m}$, average valley density $1,49 \mathrm{~km} / \mathrm{km}^{2}$ and erosional down-cutting depth about $18 \mathrm{~m}$.

Fluvial-accumulative relief of the Stryvihor basin was formed in three tiers [10]: 1) the oldest and highest one is Pliocene-Eocene-Pleistocene Loyeva with heights 100$120 \mathrm{~m}$ above the rivers and altitudes about $300 \mathrm{~m}$ (in Carpathians they can reach 500 $\mathrm{m})$. Loyeva tier is presented by accumulative massive created by the big rivers; 2 ) the middle tier presented by fourth and fifth terraces is not retained in the Stryvihor catchment; 3) the lower tier is presented by young terraces (first and second) and is well developed in the lower part of the Stryvihor river. This tier keeps primary accumulative form of the plain relief with altitudes $260-280 \mathrm{~m}$ and valley density $0,46-2,9 \mathrm{~km} / \mathrm{km}^{2}$ and erosion down-cutting $1-20 \mathrm{~m} \mathrm{[10].}$

Geomorphologic processes on the slopes are presented by the sheet and linear erosion caused by steep slopes, poor erosion resistance of the sediments and intensive rains. Within the floodplain the side and bottom erosion in the river beds are often observed as well as swamping of the relief depressions. The eroded areas amount up to $40 \%$ of the arable lands. Somewhere erosion causes washing out of $1 \mathrm{t}$ fertile soil layer per 1 year [2].

Northern part of the Stryvihor river basin is flat-wavy upland with altitudes 300$320 \mathrm{~m}$. The landscape here is presented by interchange of wavy hills and floodplains. Almost whole interfluve and water-divided areas except river valleys are covered by podzolic chornozems with high humus percentage. Uplands and top of the hills are covered by grey, light-grey and dark-grey podzolic soils. In the Bolozivka river valley the complex of thick sod-gley meadow soils has been formed. Natural vegetation cover is presented by floodplain meadows which are used for pasture and more rarely oak forests with a touch of some fir. This part of the basin is densely settled and is characterized by high percentage of arable lands. 
Southern part of the river basin occupies the Upper-Dnister valley and looks like flat swamped plain with very low erosion cutting and thin alluvium layer. There are two types of landscapes here: floodplain with bogs and swamped meadows and low terraces with meadows. Natural vegetation here is formed by meadow and swamp plants association [10].

Agricultural fields (pastures, meadow haylands on the floodplain and arable lands) are situated on the low terraces. Agricultural percentage of the catchment is relatively high and amounts $56 \%$. Cultivated fields form about $68 \%$ of the total agricultural area [10].

Natural landscapes in the basin are preserved only in the headwaters of the Stryvihor river. Highest forestry is characteristic for upper (mountain) part of the catchment (Figure 1). Most typical geomorphologic process here is sheet erosion. Almost $65 \%$ of autochthonic forests are displaced by forest monoculture or sparse growing trees.

So the Stryvihor river basin is not homogenous by the natural and socioeconomical conditions. The upper mountain part within the territory of Poland is characterized by slight economical development and higher forestry due to forced resettle of Ukrainians by the communist governments during liberation war carried out by the Ukrainian Insurgent Army. Since Ukrainians dominated in this region before 1950 , these territories became uninhabited or sparsely populated with very poor economical activities. So the man-made pressure upon the geosystems has been considerably decreased in comparison with the territory of modern Ukraine.

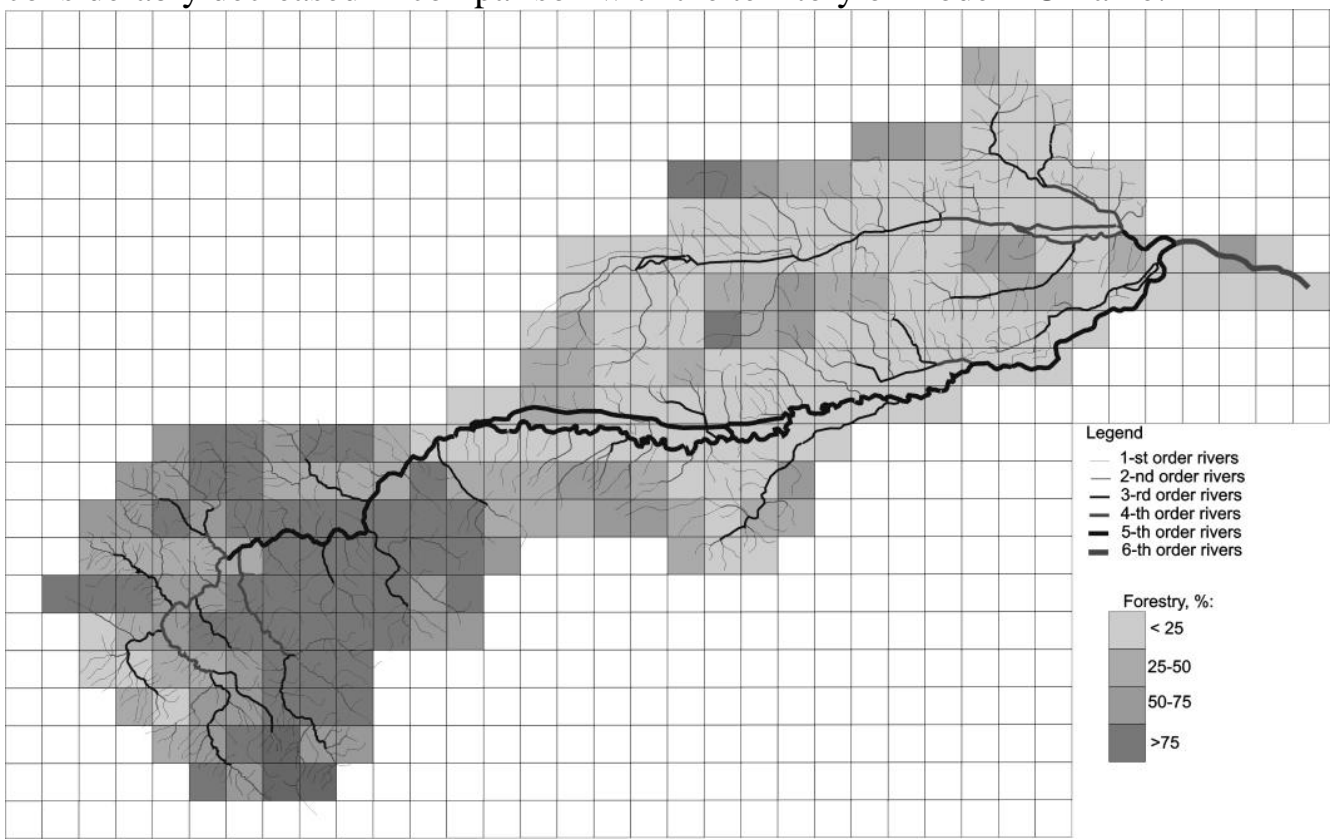

Figure 1. Forestry in the Stryvihor River basin, \%

Results and discussion. By the landscapes and hydrographic network particularities a few river systems can be segregated (Figure 2): the Stryvihor headwaters - the river of 4-th order in Polish part of the Beskyds; left tributary of 4-th order - river Lodyna, which is characterized by small area but special river structure 
pattern; right tributary of 4-th order - Stebnyk river; the biggest left tributary of 5-th order - Bolozivka river with Bolotnia tributary (in the plain part of the basin) and Ukrainian part of the Stryvihor which has 5-th order in the middle and lower part and forms 6-th order by joining the Bolozivka. Sixth order river runs to the Dnister through $8,8 \mathrm{~km}$ length.

The main river bed of the Stryvihor starts as the first order stream of 1,1 km length. Near Lodyna town the Stryvihor joints with two tributaries - the Lodyna and the Stebnyk rivers. The river network density amounts here $3-5 \mathrm{~km} / \mathrm{km}^{2}$. The river network pattern is plume type. The average length of first and second order streams is about $1,1 \mathrm{~km}$. The structure of river systems is presented in Tables 1-5 and Figure 2.

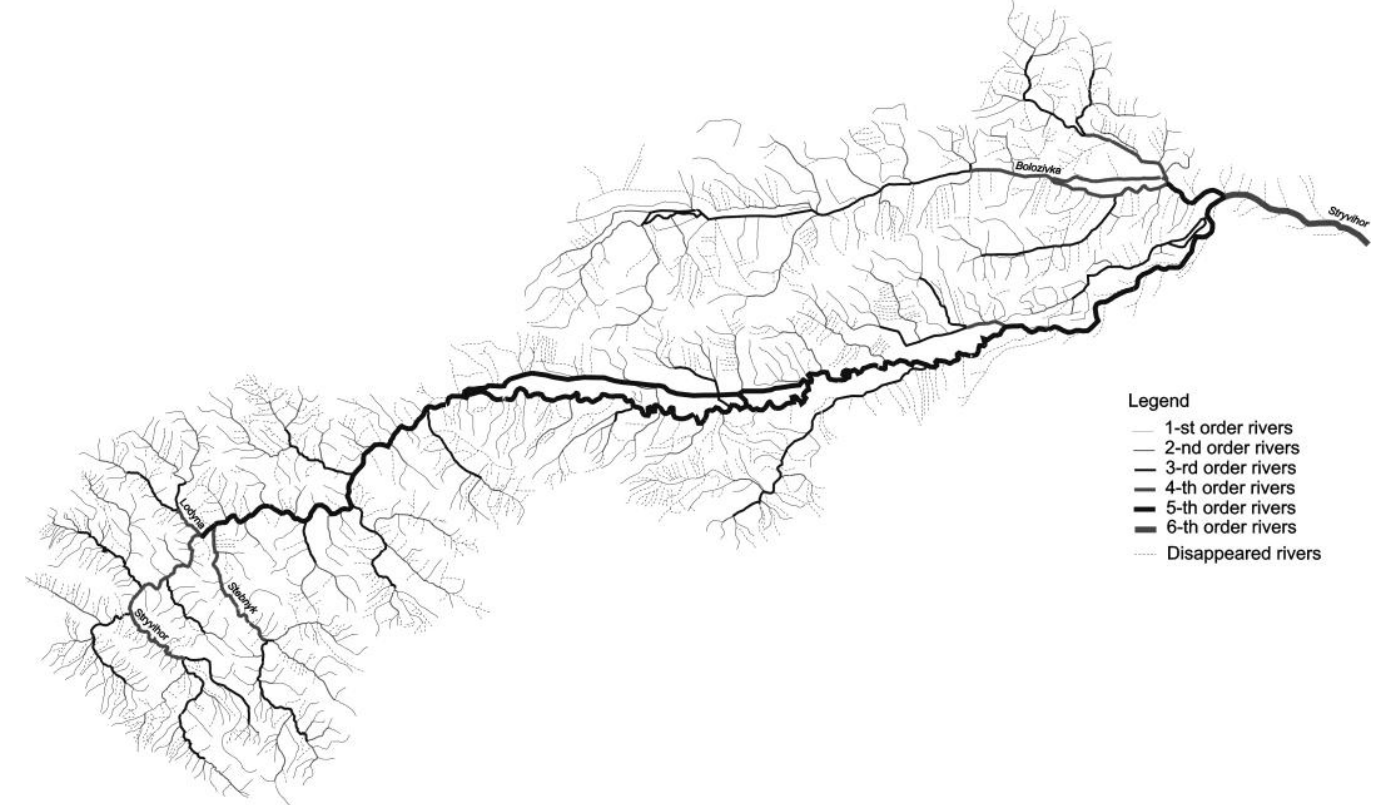

Figure 2. River system structure of the Stryvihor

Table 1

Structure of the Stryvihor headwaters

\begin{tabular}{|c|c|c|c|c|c|c|}
\hline \multirow{2}{*}{$\begin{array}{c}\text { River } \\
\text { order }\end{array}$} & \multicolumn{3}{|c|}{ River amount } & \multicolumn{3}{|c|}{ River length, km } \\
\cline { 2 - 7 } & Total & $\%$ & $\begin{array}{c}\text { Bifurcation } \\
\text { coef }\end{array}$ & Total & $\%$ & Average \\
\hline 1 & 119 & 79,90 & 4,96 & 135,7 & 67,10 & 1,14 \\
\hline 2 & 24 & 16,10 & 4,80 & 28,9 & 14,30 & 1,20 \\
\hline 3 & 5 & 3,40 & 5,00 & 26,7 & 13,20 & 5,34 \\
\hline 4 & 1 & 0,70 & 5,00 & 11,0 & 5,40 & 11,00 \\
\hline
\end{tabular}

The important structure parameter is bifurcation coefficient. If the coefficient is equal 2 than all rivers by joining in pares form a river of next higher order. Bifurcation coefficient 4 means that $50 \%$ of the streams do not form a river of higher order. According to the results of the geomorphologists research higher bifurcation coefficient reflects high sensitivity of the river system to man-made influences and low resistance against the transformations. 
The river system structure of the Lodyna river is presented in Table 2.

The Lodyna catchment is characterized by river network density $4-5 \mathrm{~km} / \mathrm{km}^{2}$. Most of the low order rivers have NE - SW direction. Average length of the 2-d order rivers is considerably higher and amounts $2,2 \mathrm{~km}$. Lodyna and Stebnyk rivers catchments are characterized by high forestry and low economic development. In second half of the XX-th century without considerable man-made pressure the Stebnyk river became stable and balanced fluvial geomorphologic system.

Table 2

Structure of the Lodyna river

\begin{tabular}{|c|c|c|c|c|c|c|}
\hline \multirow{2}{*}{$\begin{array}{c}\text { River } \\
\text { order }\end{array}$} & \multicolumn{3}{|c|}{ River amount } & \multicolumn{3}{|c|}{ River length, km } \\
\cline { 2 - 7 } & Total & $\%$ & $\begin{array}{c}\text { Bifurcation } \\
\text { coef }\end{array}$ & Total & $\%$ & Average \\
\hline 1 & 30 & 81,10 & 7,50 & 28,5 & 64,80 & 0,95 \\
\hline 2 & 4 & 10,80 & 2,00 & 8,8 & 20,00 & 2,20 \\
\hline 3 & 2 & 5,40 & 2,00 & 5,0 & 11,40 & 2,50 \\
\hline 4 & 1 & 2,70 & 2,00 & 1,7 & 3,90 & 1,70 \\
\hline
\end{tabular}

Table 3

Structure of the Stebnyk river

\begin{tabular}{|c|c|c|c|c|c|c|}
\hline \multirow{2}{*}{$\begin{array}{c}\text { River } \\
\text { order }\end{array}$} & \multicolumn{3}{|c|}{ River amount } & \multicolumn{3}{|c|}{ River length, km } \\
\cline { 2 - 7 } & Total & $\%$ & $\begin{array}{c}\text { Bifurcation } \\
\text { coef }\end{array}$ & Total & $\%$ & Average \\
\hline 1 & 52 & 77,60 & 4,30 & 61,1 & 64,60 & 1,17 \\
\hline 2 & 12 & 17,90 & 6,00 & 18,4 & 19,50 & 1,50 \\
\hline 3 & 2 & 3,00 & 2,00 & 7,7 & 8,10 & 3,85 \\
\hline 4 & 1 & 1,50 & - & 7,4 & 7,80 & - \\
\hline
\end{tabular}

Table 4

Structure of the Bolozivka river

\begin{tabular}{|c|c|c|c|c|c|c|}
\hline \multirow{2}{*}{$\begin{array}{c}\text { River } \\
\text { order }\end{array}$} & \multicolumn{3}{|c|}{ River amount } & \multicolumn{3}{|c|}{ River length, km } \\
\cline { 2 - 7 } & Total & $\%$ & $\begin{array}{c}\text { Bifurcation } \\
\text { coef }\end{array}$ & Total & $\%$ & Average \\
\hline 1 & 79 & 72,50 & 3,40 & 128,4 & 55,30 & 1,63 \\
\hline 2 & 23 & 21,10 & 5,75 & 44,0 & 19,00 & 1,90 \\
\hline 3 & 4 & 3,70 & 2,00 & 47,2 & 20,30 & 11,80 \\
\hline 4 & 2 & 1,80 & - & 8,6 & 3,70 & 4,30 \\
\hline 5 & 1 & 0,92 & - & 3,8 & 1,60 & - \\
\hline
\end{tabular}

Due to the specific form of the Stryvihor watershed in the middle and lower parts and specific hydrographic pattern there are no here river subsystems of 4-th or 5th orders. The structure of the Stryvihor river of 5-th order is presented in Table 5.

Spatial particularities of the river network density changes between the years 2005 and 1875 are visualized on the created cartogram (Figure 3). Structural parameters for the considered river systems in 1875 are presented in Table 7. 
Table 5

Structure of the Stryvihor river of 5-th order

\begin{tabular}{|c|c|c|c|c|c|c|}
\hline \multirow{2}{*}{$\begin{array}{c}\text { River } \\
\text { order }\end{array}$} & \multicolumn{3}{|c|}{ River amount } & \multicolumn{3}{|c|}{ River length, km } \\
\cline { 2 - 7 } & Total & $\%$ & $\begin{array}{c}\text { Bifurcation } \\
\text { coef }\end{array}$ & Total & $\%$ & Average \\
\hline 1 & 181 & 73,90 & 3,70 & 243,4 & 51,40 & 1,34 \\
\hline 2 & 49 & 20,00 & 4,08 & 92,4 & 19,50 & 1,90 \\
\hline 3 & 12 & 4,90 & 6,00 & 58,8 & 12,40 & 4,90 \\
\hline 4 & 2 & 0,81 & - & 3,0 & 0,60 & 1,50 \\
\hline 5 & 1 & 0,40 & - & 75,6 & 16,00 & - \\
\hline
\end{tabular}

Table 6

Structure of the Stryvihor river system as a whole

\begin{tabular}{|c|c|c|c|c|c|c|}
\hline \multirow{2}{*}{$\begin{array}{c}\text { River } \\
\text { order }\end{array}$} & \multicolumn{3}{|c|}{ River amount } & \multicolumn{3}{|c|}{ River length, km } \\
\cline { 2 - 7 } & Total & $\%$ & $\begin{array}{c}\text { Bifurcation } \\
\text { coef }\end{array}$ & Total & $\%$ & Average \\
\hline 1 & 461 & 75,80 & 4,10 & 597,1 & 57,00 & 1,30 \\
\hline 2 & 112 & 18,40 & 4,50 & 192,5 & 18,40 & 1,70 \\
\hline 3 & 25 & 4,10 & 3,57 & 145,4 & 13,90 & 5,80 \\
\hline 4 & 7 & 1,20 & - & 31,7 & 3,00 & 4,50 \\
\hline 5 & 2 & 0,30 & - & 79,4 & 7,60 & - \\
\hline 6 & 1 & 0,16 & - & 8,8 & 0,80 & - \\
\hline
\end{tabular}

Table 7

Structure parameters of the Stryvihor river subsystems in the year 1875

\begin{tabular}{|l|c|c|c|c|}
\hline \multirow{2}{*}{ River system } & \multicolumn{2}{c|}{ River length, km } & \multicolumn{2}{c|}{ River amount } \\
\cline { 2 - 5 } & Total & Average & Total & Bifurcation coef (b) \\
\hline Lodyna & 58 & 1,07 & 54 & 7,70 \\
\hline Stryvihor headwaters & 185 & 0,87 & 212 & 6,60 \\
\hline Stebnyk & 112 & 1,38 & 81 & 4,30 \\
\hline Bolozivka & 288 & 1,88 & 153 & 4,50 \\
\hline Stryvihor of 5-th order & 351 & 1,08 & 325 & 5,00 \\
\hline Stryvihor as a whole & 994 & 1,20 & 825 & 5,25 \\
\hline \multicolumn{5}{|c|}{ Second order rivers } \\
\hline Lodyna & 10,2 & 1,45 & 7 & 2,30 \\
\hline Stryvihor headwaters & 34,6 & 1,07 & 32 & 4,60 \\
\hline Stebnyk & 16,2 & 0,85 & 19 & 4,80 \\
\hline Bolozivka & 58,4 & 1,71 & 34 & 5,70 \\
\hline Stryvihor of 5-th order & 145,2 & 2,23 & 65 & 3,80 \\
\hline Stryvihor as a whole & 264,6 & 1,69 & 157 & 4,20 \\
\hline \multicolumn{5}{|c|}{ Third order rivers } \\
\hline Lodyna & 7,0 & 2,30 & 3 & 3,00 \\
\hline Stryvihor headwaters & 31 & 4,43 & 7 & 3,50 \\
\hline Stebnyk & 9,7 & 2,40 & 4 & 4,00 \\
\hline Bolozivka & 60,4 & 10,10 & 6 & 3,00 \\
\hline Stryvihor of 5-th order & 75,2 & 4,40 & 17 & 5,60 \\
\hline Stryvihor as a whole & 183,3 & 4,95 & 37 & 4,10 \\
\hline
\end{tabular}


General quantitative parameter of the river system structure change is transformation coefficient in percents. It is calculated the river amount and length. According to these results the strongest changes of the structure are observed in the middle and lower parts of the Stryvihor basin where man-made impacts were most significant (Table 8).

Table 8

Transformation coefficients of different orders river amount and total length in the Stryvihor river basin

\begin{tabular}{|c|c|c|c|c|c|c|}
\hline \multirow[b]{2}{*}{ River system } & \multicolumn{3}{|c|}{ River length, km } & \multicolumn{3}{|c|}{ River amount } \\
\hline & 2005 & 1875 & $\begin{array}{c}\text { Transform. } \\
, \%\end{array}$ & 2005 & 1875 & $\begin{array}{c}\text { Transform. } \\
, \%\end{array}$ \\
\hline \multicolumn{7}{|c|}{ First order rivers } \\
\hline Lodyna & 28,5 & 58,0 & 49,14 & 30 & 54 & 55,56 \\
\hline Stryvihor headwaters & 135,0 & 185,0 & 72,97 & 119 & 212 & 56,13 \\
\hline Stebnyk & 61,1 & 112,0 & 54,55 & 52 & 81 & 64,20 \\
\hline Bolozivka & 128,0 & 288,0 & 44,44 & 79 & 153 & 51,63 \\
\hline $\begin{array}{l}\text { Stryvihor of 5-th } \\
\text { order }\end{array}$ & 243,0 & 351,0 & 69,23 & 181 & 325 & 55,69 \\
\hline Stryvihor as a whole & 597,1 & 994,0 & 60,07 & 461 & 825 & 55,88 \\
\hline \multicolumn{7}{|c|}{ Second order rivers } \\
\hline Lodyna & 8,8 & 10,2 & 86,27 & 4 & 7 & 57,14 \\
\hline Stryvihor headwaters & 28,9 & 34,6 & 83,53 & 24 & 32 & 75,00 \\
\hline Stebnyk & 18,4 & 16,2 & 113,58 & 12 & 19 & 63,16 \\
\hline Bolozivka & 44,0 & 58,4 & 75,34 & 23 & 34 & 67,65 \\
\hline $\begin{array}{l}\text { Stryvihor of 5-th } \\
\text { order }\end{array}$ & 92,4 & 145,2 & 63,64 & 49 & 65 & 75,38 \\
\hline Stryvihor as a whole & 192,5 & 264,6 & 72,75 & 112 & 157 & 71,34 \\
\hline \multicolumn{7}{|c|}{ Third order rivers } \\
\hline Lodyna & 5,0 & 7,0 & 71,43 & 2 & 3 & 66,67 \\
\hline Stryvihor headwaters & 26,7 & 31,0 & 86,13 & 5 & 7 & 71,43 \\
\hline Stebnyk & 7,7 & 9,7 & 79,38 & 2 & 4 & 50,00 \\
\hline Bolozivka & 47,2 & 60,4 & 78,15 & 4 & 6 & 66,67 \\
\hline $\begin{array}{l}\text { Stryvihor of 5-th } \\
\text { order }\end{array}$ & 58,8 & 75,2 & 78,19 & 12 & 17 & 70,59 \\
\hline Stryvihor as a whole & 145,4 & 183,3 & 79,32 & 25 & 37 & 67,57 \\
\hline
\end{tabular}

As we can see uninhabited Stryvihor headwaters, Lodyna and Stebnyk rivers are characterized by 5-10\% less amount of disappeared rivers of first order and 10$20 \%$ less shortening of their total length. Concerning other orders and river network density the similar tendencies are observed, especially with second river order length which has been even increased in the Stebnyk river system (Table 8, Figure 3).

The key factor of the small river system structure changes (decreasing of the total length and amount of the rivers) is intensive agricultural use and erosion processes. This conclusion is confirmed also by the investigations results obtained for other river systems of the region $[1-6,9-11]$. Stationary and semistationary observations in the Precarpathians and Podillia testify that soil washout intensity on the cultivated slopes amounts $0,001-3,5 \mathrm{~mm}$ annually, within the cultivated valleys $-0,06-0,83 \mathrm{~mm}$, and 
in the 1-st order catchments - 0,06-0,23 $\mathrm{mm}$ annually [5]. At the same time in foothills, lower parts of the slopes and valley bottoms about $40-65 \%$ of the products are redeposited, $30-46 \%$ of the products are carried out of the catchment. Bigger part of the washed out soil products (up to $60-80 \%$ ) is accumulated within the floodplains and shorelines of the low order rivers, about $11-43 \%$ of the products falls into the river bed [5]. This process usually caused the river beds silting.

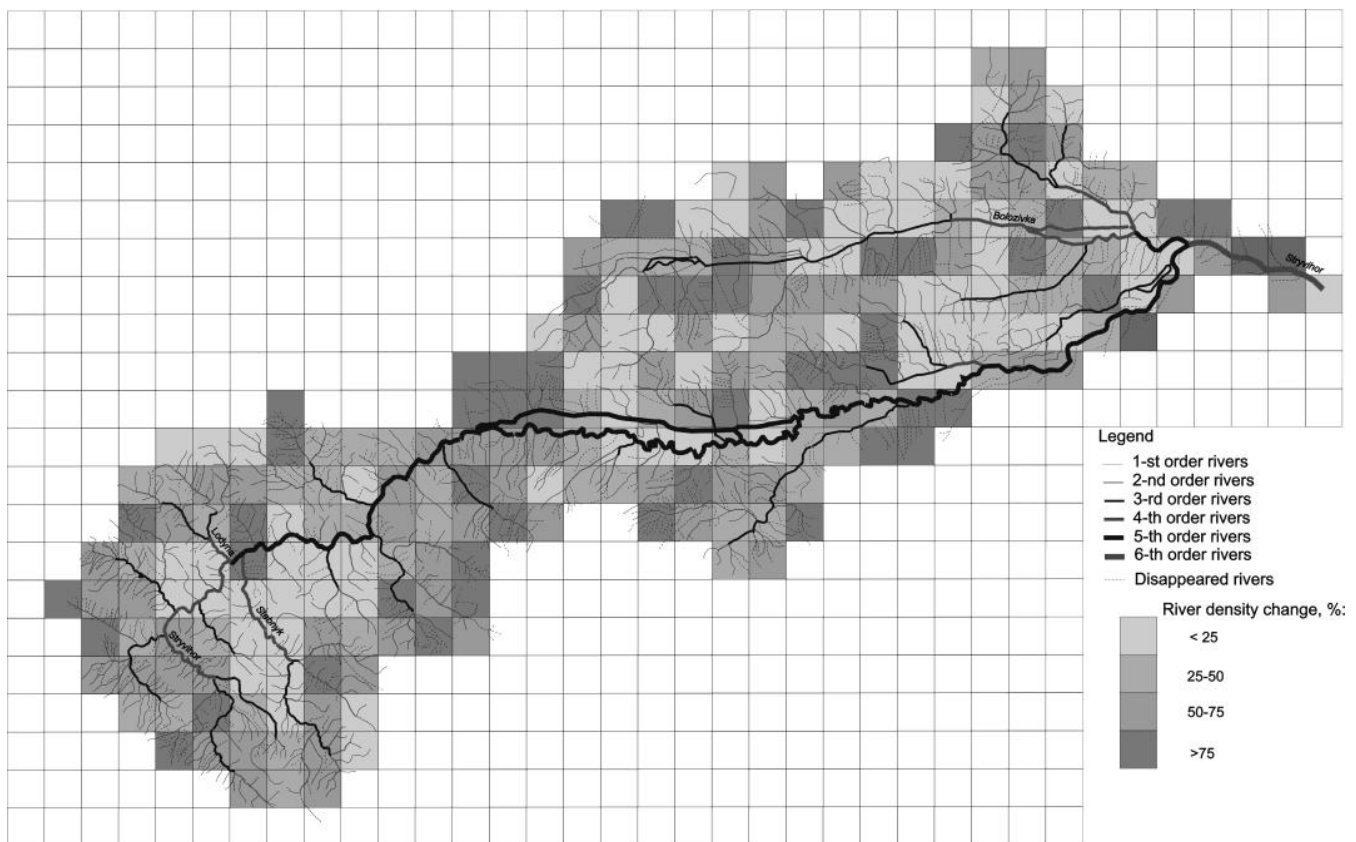

Figure 3. The Stryvihor River network density change in the period 1875 - 2005

Conclusions. In the mountain part of the river basin small rivers of first and second orders with length $1-1,5 \mathrm{~km}$ dominate. In the foothills and premountain part the average length and bifurcation coefficient increase but the share of low orders decreases. In the lower part within the lowland the natural river systems structure is transformed due to saturating by drainage canals.

Typical for the Stryvihor river basin very high bifurcation coefficients, especially in the upper mountain part $(b=5-6)$, testify about strong sensibility and poor stability of the rivers against man-made pressure and different economical activities. In compare to year 1875 the ratio between different orders has changed on 10-25\%. Maximal changes (amount decreasing) have been ascertained in water dividing areas as well as in the Bolozivka and middle part of the Stryvihor rivers.

The river structure transformation parameters concur with economical development of the territory, forestry and relief morphometric parameters as well.

The results of carried out investigations consist the base for measures on ecosystems renaturalization, ecological situation improving, risk of adverse and dangerous geomorphologic processes mitigation, water resources management the conditions of human being optimization etc. 


\section{REFERENCES}

1. Dubis L. (1995). The structure and functioning of the mountain part of Tysa basin river systems. Extended abstract of candidate's thesis. Lviv (in Ukrainian).

2. Kovalchuk I. (1997). Regional ecological-geomorphologic analysis. Lviv, 440 pp. (in Ukrainian).

3. Kovalchuk I., Shtoyko P. (1992). Western Podillia river systems changes in VIII XX centuries. Geomorphology, 2, pp. 55-72 (in Russian).

4. Kovalchuk I., Volos S., Kholod'ko L. (1992). Tendencies and causes of Western Ukraine river systems changes in XIX-XX centuries. Geography and natural resources, 2, pp. 102-110 (in Russian).

5. Kravchuk Y. (1999). Geomorphology of the Precarpathians. Lviv: Merkator, 188 pp. (in Ukrainian).

6. Kurhanevych L. (2001). Ecological-geomorphologic analysis of the Western Bug basin. Extended abstract of candidate's thesis. Lviv (in Ukrainian).

7. Kyseliov Y. (2000). Degradation of the Donets'k ridge northern slope river systems. Visnyk of Lviv University. Series Geography, 27, pp. 122-130 (in Ukrainian).

8. Mykhnovych A. (1998). The Upper Dnister river systems structure and its transformation under natural and man-made factors. In: Geography of Ukraine (regional problems). Visnyk of Lviv University. Series Geography, 21, pp. 161-167 (in Ukrainian).

9. Pavlovs'ka T. (2006). The Horyn' river system: structure, functioning, management. Extended abstract of candidate's thesis. Lviv (in Ukrainian).

10. Stryvihor River passport. Lviv: Regional Water Management Authority. 325 pp. (in Ukrainian).

11. Volos S. (1999). Historic-geographic aspect of man-made transformation of the Carpathian part of Dnister basin river systems. Visnyk of Lviv University. Series Geography, 24, pp. 120-123 (in Ukrainian).

12. Yedynak N. (2000). Ecological-geographic analysis of the Cheremosh river basin. Visnyk of Lviv University. Series Geography, 27, pp. 72-77 (in Ukrainian).

\section{СТРУКТУРА РІЧКОВИХ СИСТЕМ СТРИВІГОРУ І ÏÏ ЗМІНИ}

\section{Андрій Михнович}

\section{Львівський національний університет імені Івана Франка, вул. П. Дороменка 41, 79007, Львів, Україна}

\footnotetext{
Зрівноважений розвиток річкових басейнів потребує вивчення просторово-часової динаміки річкових систем, які є центральним інтегруючим компонентом водозбору. Особливо це стосується структури річкових систем і їі перебудови. Зважаючи на відмінності у рівні господарського освоєння басейну річки Стривігор в межах Польщі та України, ця річка $є$ цікавим об'єктом вивчення у плані оцінки впливу на зміни структури річкових систем сільськогосподарської діяльності, лісистості, селитебного навантаження тощо. Об'єктом досліджень є басейн річки Стривігор, а метою - оцінка структури річкових систем басейну, тенденцій і масштабів ії змін. Структура річкових систем аналізується за допомогою класифікаційної схеми Стралера - Філософова із
} 
застосуванням методів картометричного і статистичного аналізу, картографування та інших. Інформаційною базою досліджень $є$ різночасові топографічні карти масштабу 1:100 000. Структура річкових систем і iі зміни аналізуються шляхом визначення $\mathrm{i}$ розрахунку низки морфометричних параметрів і порівняння коефіцієнтів трансформації та щільності річкової мережі станом на 1875 і 2005 роки. Верхів'я Стривігору, а також річки Лодина і Стебник (територія Польщі) характеризуються на 5-10\% меншим скороченням кількості зниклих за досліджуваний період водотоків і на $10-20 \%$ меншим скороченням загальної довжини водотоків низьких порядків. Характерні для річкових систем басейну Стривігору дуже високі коефіцієнти біфуркації водотоків вказують на високу чутливість i слабку стійкість річкових систем до антропогенних навантажень $\mathrm{i}$ господарської діяльності. У порівнянні з 1875 роком співвідношення між водотоками різних порядків зазнало змін у середньому на $10-25 \%$.

Ключові слова: структура річкової системи, порядок річки, щільність річкової мережі. 